\title{
Macroeconomic Effects of the European Monetary Union: A Counterfactual Analysis
}

\author{
By Constantin Colonescu*
}

This is an empirical study on the effects of adopting a common currency, the euro, on a country's GDP, inflation rate, and public debt. It uses a synthetic counterfactual method, which predicts how the economy of a euro area member country would perform if, hypothetically, the country did not join the euro area. The results show that there is no generally positive or negative effect of using a common currency, but individual countries fare differently in different periods. A novelty in this paper is determining confidence intervals in the counterfactual method. Some examples concern Greece.

Keywords: monetary union; euro; synthetic counterfactual

\section{Introduction}

Exchange rates have been an issue for as long as money existed. Historically, European countries have seen and experienced all degrees of exchange rate arrangements, ranging from fixed exchange rates (the gold standard and the Bretton Woods systems), to fully flexible (some countries in different periods), semi-flexible (the European currency "snake"), and fixed but adjustable rates; for example, the Exchange Rate Mechanism of the 1980s. None of these lasted for a very long time, since none stripped a government of its ability to print money when needed. As opposed to all these regimes, in a monetary union the creation of money is delegated to a supra-national central bank. The architects of such a system hope that it would live longer than any other. The present study attempts to evaluate the modern European common currency system, solving a counterfactual exercise, which compares a country with a control group. It finds that adopting a common currency has mixed effects on different monetary union members.

After long periods in which European economies experienced exchange rate instability and financial turmoil, the leaders of a few European Union countries decided to adopt a common currency, the strongest form of a fixed exchange rate regime. The idea of a European monetary union started to take shape back in 1988 and has undergone a lengthy process of coming into existence up until 2002, when euro bills and coins started to circulate in 12 of the 15 EU member countries.

Optimum currency area theories identify the factors that influence the success of a monetary union. According to these, a monetary union might work if labour is internationally mobile, if governments have similar preferences in terms of monetary and fiscal policies, if economies are diversified but have a

* Assistant Professor, MacEwan University, Canada. 
similar structure of production, if there is a high degree of openness to movement of goods, capital, and labour, and if there is a sense of solidarity among the people in the monetary union member countries. While European Union member countries fare well on goods and capital mobility, there is still much to do to improve labour mobility: some EU member countries are more open than others to a foreign influx of workers.

Some discrepancies are also visible in governments' preferences toward fiscal discipline. When new governments take over, fiscal policies may change, such that a country could become more or less exposed to balance of payments misalignments. Thus, a country might be temporarily better off as a monetary union member, but it might also be temporarily worse off. There is no guarantee that adopting a common currency is going to be advantageous at all times.

Like most economic decisions, adopting a common currency has its costs and benefits (Vickers, 2000). While the optimum currency criteria may provide some guidance, determining the net effect of monetary integration poses an empirical problem, which is investigated in this study. The results show that there is no general rule concerning the effect of common currency on a national economy: each country may benefit or not for some periods, an effect which may possibly be reversed in other periods. This study examines the effect of adopting the euro on three variables: GDP in twelve euro area member countries; inflation in eight and.; government debt in eight countries. The control group includes about 40 countries, observed from 1996 (three years before the European Monetary Union took effect) to 2015.

\section{Literature Review: Economic Effects of Monetary Integration}

In recent years, economists have paid relatively little attention to the effect of monetary integration on macroeconomic variables. Here are a few examples of such efforts, which show mixed results.

Conti (2014) uses a difference in differences model, finding that the adoption of the euro may have raised GDP per capita growth in 17 European countries by about 4 percent as of 2010. On the other hand, Kalaitzoglu and Durgeu (2016) show that neither economic nor monetary integration have a significant effect on growth in the European Union. The authors identify two channels through which monetary integration may connect to growth: better access to financing, which enhances growth, and a macroeconomic risk of over-borrowing, which may reduce long term growth. They conclude that "the suitability of adopting the Euro should depend on each country's ability to balance [...] the improved access to financing and the risk of over-borrowing" (Kalaitzoglu and Durgeu, 2016).

Papanikos (2015) explains part of the post-2009 economic downturn in Greece and other Eurozone countries, using the concept of euro overvaluation with respect to the dollar. The author argues that countries with a history of high inflation such as Greece are unable to adjust their price levels to offset an 
overvalued currency, which results in long term recessions. A history of high inflation, however, should act in favour, not against adopting an anchor currency such as the euro according to Alessina and Barro (2002). Papanikos (2015) estimates the loss in Greek GDP due to real exchange rate misalignment at 1.25 percent per year.

Does a certain exchange rate regime favour economic growth more than another? Economic studies answer this question both ways. Based on a panel of 60 countries observed over the 1973-1998 period, Bank of Canada research shows strong evidence that a floating exchange regime positively influences economic growth (Bailliu, Lafrance, \& Perrault, 2002). Another study conducted by Baikan (2016) uses a set of 164 countries and finds no significant effect of exchange rate regime on growth. An article published in the American Economic Review (Levy-Yevati and Sturzenegger, 2003) finds that the exchange rate regime has different effects on developing than on developed economies: less flexible exchange rate regimes impede growth in developing countries, while the exchange rate regime does not seem to matter in developed countries.

This brief literature overview suggests that monetary integration viewed as an exchange rate regime has very different effects on different countries, but the mechanisms through which it affects the economy are yet to be understood.

\section{Method and Data}

This paper uses the synthetic counterfactual method developed by Abadie, Diamond, and Hainmueller (2010) and Imbens and Wooldridge (2009) to estimate the GDP of a euro area member country if, hypothetically, the country would not have joined the euro area. Since the seminal work of Abadie and Gardeazabal (2003), more and more studies have used the synthetic counterfactual approach, covering a variety of topics. For example, Campos, Coricelli, and Moretti (2014) investigate the effect of European Union membership on GDP in the countries of the 2004 wave of EU enlargement. Billmaer and Nanncini (2013) study the effect of trade liberalization on GDP. Montalvo (2011) asks whether the Spanish elections of 2014 would have had a different outcome if the terrorist attack in Madrid did not take place three days before the elections. Finally, El-Shagi, Lindner and Schweinitz (2014) evaluate the extent of misalignment in real exchange rates in European countries using the pre-euro period as a matching standard.

The R Synth package estimates the impact of an event (aka treatment, intervention, or exposure) on a research subject by constructing a counterfactual, a virtual situation that might have prevailed in the absence of the event (Abadie, Diamond and Hainmueller, 2011). The construction of the counterfactual involves the following stages: (i) Formation of a control group of countries that will be used for comparison to the country under study; (ii) Construction of a counterfactual, a virtual country that resembles the country under study along the lines of several attributes (predictors), such as 
government spending, education, and investment. This "synthetic" counterfactual is a weighted average of the countries in the control group, with the weights determined such that the counterfactual best estimates the mean of the output variable (such as GDP) in the country under study over the pretreatment period; (iii) Prediction of the evolution of the outcome in the posttreatment period using the weights determined at stage (ii),; (iv) finally, comparison of the actual (treated) country to its counterfactual to assess the effect of the treatment. The calibration of the model uses two sets of weights: one that assigns a weight for each country in the control group, and one that assigns a weight to each predictor.

Let us establish a few notations (closely following the original "synth" function):

$K=$ number of predictors. Predictors are country attributes such as those presented in Table 1. The attributes may or may not be chosen based on some causal theory; they are just meant to describe how similar or different a country is with respect to the countries in the control group.

$N=$ the number of countries in the control group.

$T_{1}=$ number of periods (years of observation) before treatment.

$X_{1}=$ the $(K \times 1)$ vector of predictor values in the treated country.

$X_{0}=$ the $(K \times N)$ matrix of predictor values in the $N$ control countries.

$Z_{1}=$ the $\left(T_{1} \times 1\right)$ vector of actual outcomes (GDP) for the treated country before treatment.

$Z_{0}=$ the $\left(T_{1} \times N\right)$ matrix of actual outcomes (GDP) for the control countries before treatment.

$V=$ the $(K \times K)$ diagonal matrix of predictor weights.

$W=$ the $(N \times 1)$ vector of country weights.

$Y_{1 t}=$ the counterfactual dependent variable in the exposed country at time $t$.

$Y_{0 t}=$ the $(N \times 1)$ matrix of the variable of interest for the control countries.

The "synth" algorithm determines the weights $w_{i}$, used to minimize the distance between the control group's predictor values $\left(X_{0}\right)$ and the treated predictor values $\left(X_{1}\right)$ under the conditions that the weights are positive and sum to 1 :

$W=\operatorname{Argmin}\left(X_{1}-X_{0} W\right)^{\prime} V\left(X_{1}-X_{0} W\right)$

where $V$ is chosen to minimize the mean square error of the estimated counterfactual. In other words, $V$ is selected such that the counterfactual best fits the GDP of the trated country:

$V^{*}=\operatorname{Argmin}\left(Z_{1}-Z_{0} W^{*}(V)\right)^{\prime}\left(Z_{1}-Z_{0} W^{*}(V)\right)$ 
Once the two sets of weights are determined, the predicted values of the treated country are, for each period $t$,

$Y_{1 t}=\sum_{i=1}^{N} w_{i} Y_{0 t}$

Solving equations (1) and (2) involves an iterative process. Given the constraints on the weights may not be exact the counterfactual outcome potentially differs from the actual outcome in the period prior to treatment. Another reason for the divergence of the counterfactual from the actual outcome before treatment is that the weights $W$ and $V$ are determined for the average predictor values in the pre-treatment period.

The R software package "Synth" (Abadie et al., 2011) computes and plots the path of an outcome variable (such as GDP, inflation, or government debt) using the synthetic counterfactual method. In this context, becoming a member of the European monetary union is the treatment under study.

Although the synthetic counterfactual method seeks to establish no causal relationship between the predictors and the outcome, the method seems to work better if the choice of the predictors is based on macroeconomic theory. The factors explaining economic growth are chosen in line with neoclassical growth theories, which identify several categories of such factors: technological change, physical capital, human capital, initial development (Solow, 1956; 1957; Swan, 1956; Mankiw, Romer, and Weil, 1992; Breton, 2013); trade liberalization (Baldwin and Forslid, 2000); and government policies (Eisner, 1992).

Table 1 shows the predictor variables, chosen to represent these broad theoretical categories. The choice of such variables is becoming standard in synthetic counterfactual literature on macroeconomic issues (Abadie and Gardeazabal, 2003; El-Shagi et al., 2014; Campos et al., 2014; Billmaer and Nanncini, 2013).

Two predictors in Table 1 require further discussion. The first is an indicator variable for euro area membership, which is equal to 1 for a euro area member country and 0 for a non-member. The original synthetic counterfactual method does not require such a variable because, according to the original method no other country in the control group would be exposed to the treatment.

Instead of using a binary indicator for EU membership, Abadie et al. (2011, p. 3) recommend aggregating the data if more than one country is exposed to treatment. Aggregation, however, only leads to an aggregate result, which is an answer to the question whether the euro area countries are better off on average; the truly interesting question concerns, though, individual countries rather than averages. 
Table 1.Variables and their WDI Database Codes

\begin{tabular}{|l|l|}
\hline \multicolumn{1}{|c|}{ Definition } & Code \\
\hline GDP (constant 2005 US\$) (the variable under study) & NY.GDP.MKTP.KD \\
\hline Government consumption (constant 2005 US\$) & NE.CON.GOVT.KD \\
\hline Gross fixed capital formation (constant 2000 US\$) & NE.GDI.FTOT.KD \\
\hline Industry, value added (constant 2000 US\$) & NV.IND.TOTL.KD \\
\hline Export value index (2000 = 100) & TX.VAL.MRCH.XD.WD \\
\hline Population, total & SP.POP.TOTL \\
\hline Agriculture value added per worker (constant 2000 US\$) & EA.PRD.AGRI.KD \\
\hline CO2 emissions (kg per 2000 US\$ of GDP) & EN.ATM.CO2E.PP.GD.KD \\
\hline CO2 intensity (kg per kg of oil equivalent energy use) & EN.ATM.CO2E.EG.ZS \\
\hline Urban population growth (annual \%) & SP.URB.GROW \\
\hline Population ages 15-64 (\% of total) & SP.POP.1564.TO.ZS \\
\hline Mobile cellular subscriptions (per 100 people) & IT.CEL.SETS.P2 \\
\hline Labor participation rate, female (\% of female population ages 15+) & SL.TLF.CACT.FE.ZS \\
\hline Tariff rate, applied, simple mean, primary products $(\%)$ & $\begin{array}{l}\text { TM.TAX.TCOM.SM.AR.Z } \\
\text { S }\end{array}$ \\
\hline EU membership (=1 if country is member) & EU.member \\
\hline Eurozone membership (=1 if Eurozone member) & Euro.member \\
\hline
\end{tabular}

Table 2 shows summary statistics for GDP and its predictors. The data come from World Bank's WDI data base (World Bank, 2016), covering 42 countries in the period between 1996 and 2015.

Table 2. Descriptive Statistics

\begin{tabular}{|l|r|r|r|r|r|}
\hline & \multicolumn{1}{l|}{$\ln$} & \multicolumn{1}{l|}{$\max$} & \multicolumn{1}{l|}{ median } & \multicolumn{1}{l|}{ mean } & \multicolumn{1}{l|}{ std.dev } \\
\hline GDP & $3.45 \mathrm{E}+09$ & $1.65 \mathrm{E}+13$ & $2.88 \mathrm{E}+11$ & $1 \mathrm{E}+12$ & $2.29 \mathrm{E}+12$ \\
\hline Gov. consumption & $6.86 \mathrm{E}+08$ & $2.52 \mathrm{E}+12$ & $5.74 \mathrm{E}+10$ & $1.78 \mathrm{E}+11$ & $3.73 \mathrm{E}+11$ \\
\hline Capital formation & $-1.5 \mathrm{E}+09$ & $4.07 \mathrm{E}+12$ & $5.76 \mathrm{E}+10$ & $2.31 \mathrm{E}+11$ & $5.45 \mathrm{E}+11$ \\
\hline Ind. value added & $7.12 \mathrm{E}+08$ & $4.09 \mathrm{E}+12$ & $7.05 \mathrm{E}+10$ & $2.54 \mathrm{E}+11$ & $5.62 \mathrm{E}+11$ \\
\hline Export & 54.2599 & 1031.644 & 181.7768 & 242.2794 & 177.9023 \\
\hline Population, total & 268916 & $1.37 \mathrm{E}+09$ & 10301480 & 91931324 & $2.61 \mathrm{E}+08$ \\
\hline Agric. value added & -1139.95 & 219244.5 & 15633.67 & 26323.14 & 26071.69 \\
\hline CO2 emissions & 0.054007 & 1.753345 & 0.272172 & 0.344743 & 0.215897 \\
\hline CO2 intensity & -2.38589 & 4.198001 & 0.529617 & 0.670382 & 1.074538 \\
\hline Urban pop. growth & 0.044809 & 4.6566 & 2.377309 & 2.311866 & 0.665117 \\
\hline Population 15-64 & 56.11841 & 74.35314 & 67.16426 & 67.14883 & 2.526306 \\
\hline Mobile phone & 0.011862 & 172.3224 & 90.09603 & 78.33732 & 47.2804 \\
\hline Labor partic. & 18.3 & 72 & 51.7 & 50.26181 & 9.64422 \\
\hline Tariff rate & -8.13241 & 88.27 & 6.37 & 8.147762 & 8.216037 \\
\hline
\end{tabular}

The membership indicator allows the use of other euro area members as control units. It also facilitates the provision of an answer to the following question:

"What a country's GDP would have been if the country did not join the euro area, while the other countries did?" 
as opposed to the less interesting question:

"What a country's GDP would have been if the country did not join the euro area and the other countries in the euro area did not exist at all?"

In the absence of such a variable, the validity of the control group is evaluated by performing a placebo test, by simply feeding to the synthetic counterfactual algorithm the information that a country, say Norway, is treated when it is in fact not treated (Abadie et al., 2010, p. 501). Such a test only works under the assumption that the control countries are not affected by the treatment. This assumption, however, is most likely incorrect in the case of the euro membership problem. Other studies, such as the one conducted by Campos et al. (2014), do not address the problem of interaction among the treated units or between the treated units and the control group. The membership indicator is designed to account for potential interferences between the treated and the control units. Unrelated methods, such as panel data VAR also consider the issue of cross sectional correlation in panel data models (Dees, Mauro, Pesaran and Smith, 2007).

The issue of interdependence between a treated unit and other units; treated or not; deserves closer attention. Mutual influence should be expected when there are spillovers or network externalities as it is the case with a monetary union; the more countries are in the union, the greater are the expected gains for each member. A monetary union, by its very reason of existence, is supposed to be a gain-gain situation when the right conditions are present. On the other hand, setting up a regional agreement such as a free trade or a common currency area could negatively affect traditional trading partners that are not included in the newly-established regional arrangement. Synthetic counterfactual models may be suitable to address such situations, provided appropriate control variables are included, which is the role of the membership indicator used in the present study. There is yet no theory or method to address the violation of cross-sectional interdependence in the synthetic counterfactual method.

When interdependence among cross-sectional units is allowed, the synthetic counterfactual method stands apart from other treatment effect models, because the strong separation between treated and non-treated units fades. For instance, if we ask how Slovenia would perform if it did not join the euro area, the control group should include all countries in the sample, euro members or not. In other words, when asking if euro is good for Slovenia, we do not seek to find out whether forming a monetary union in the EU is good or bad on average, as treatment effect methods do. Whether monetary integration is desirable or not for a particular country depends, in part, on the other countries in the euro area. Previous research, which assumes complete independence, does not seem to address this important issue.

Another predictor that might have an important role in determining the effect of the common currency on GDP is European Union membership: the membership indicator would be equal to 1 for an EU member and 0 for a non- 
member. As the results presented below suggest, being an EU member seems to enhance the gain (or reduce the loss) from being a euro area member. The reason behind including this predictor is that it relates to the optimal currency area criteria: EU membership brings about enhanced labour and capital mobility and a forum for political discussion.

Taking into account all these aspects concerning the control group, the following countries were chosen to form our sample: Argentina, Australia, Austria, Belarus, Belgium, Bulgaria, Brazil, China, Czech Republic, Denmark, Egypt, Estonia, Finland, France, Germany, Greece, Hungary, Iceland, India, Ireland, Italy, Lithuania, Luxembourg, Latvia, Republic of Macedonia, Moldova, Norway, Poland, Portugal, Romania, Russian Federation, Serbia, Slovak, Republic, Slovenia, Spain, Sweden, Switzerland, Turkey, Ukraine, United Kingdom, and United States of America. The countries have been chosen such that the control group include as many and as diverse categories: developed and less developed countries, various geographical regions, and large and small economies. A country is removed from the sample when it becomes the treated entity.

\section{Results}

Figure 1 shows the evolution of GDP in a few European monetary union countries. For each euro member, the actual GDP is compared to a "synthetic counterfactual" GDP, which is an estimate of what the country's GDP would have been if the country did not adopt the euro. When the dotted line (the counterfactual) is below the solid line (the actual GDP with the country being in the euro area), the country would have been worse off if it did not join the euro area.

Figure 1. Actual vs. Counterfactual GDP. Vertical Dotted Line Shows the Year of Euro Area Membership
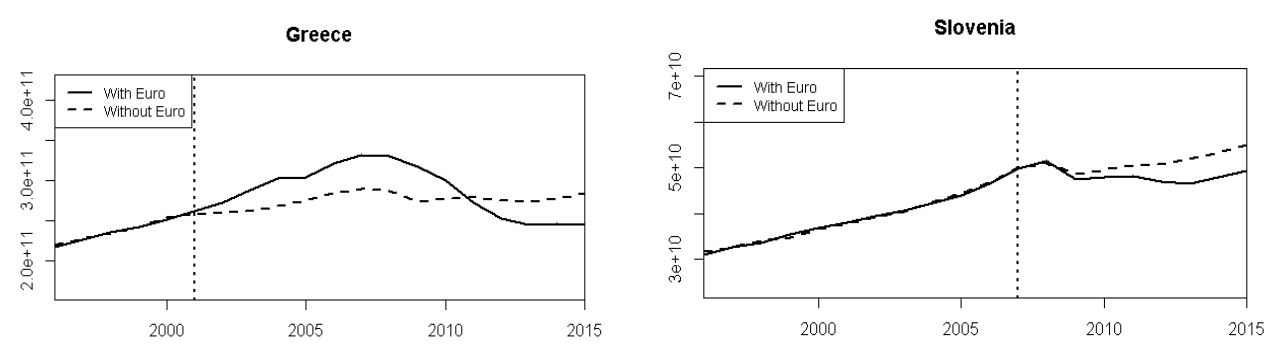

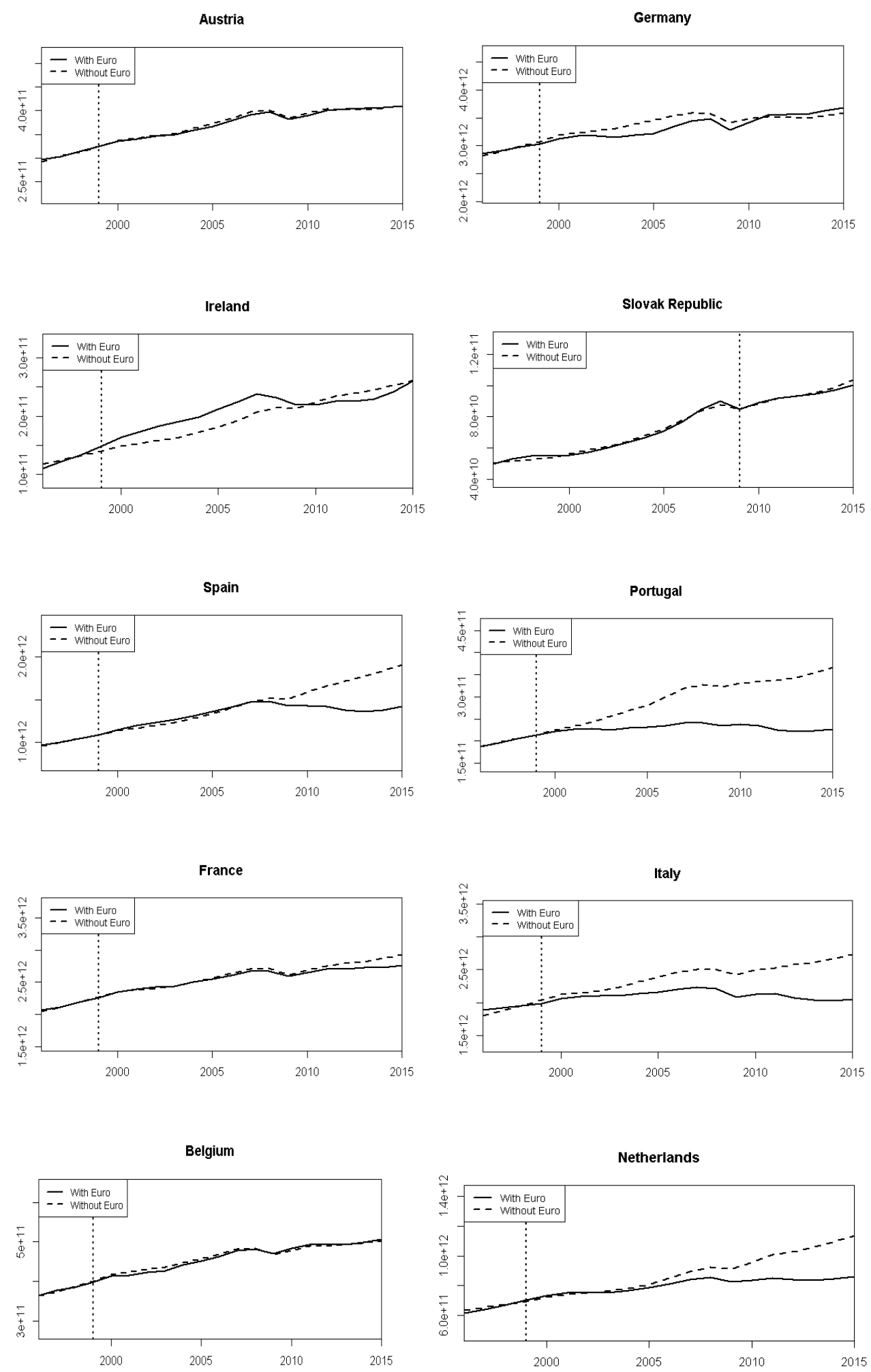

The left hand side of Figure 1 shows the countries for which adopting the euro has been, at least for some period, beneficial (Greece, Austria, Ireland, Spain, France, and Belgium.) The right hand side groups the countries for 
which euro membership appears to have been less useful or neutral (Slovenia, Germany, Slovak Republic, Portugal, Italy, and the Netherlands.) The effect of the euro does not seem to be substantially significant for some countries, (e.g., Austria, Slovak Republic, France, and Belgium.) A distinct case is Greece, where the euro appears to work well until 2010, but proves detrimental after that year. Figure 2 shows an example to suggest that accounting for European Union membership tends to enhance the estimated effect of the common currency on a country's GDP. Of course, this does not mean that a country could be in the euro area without being an EU member; it just shows that the membership indicator is an important addition to the model.

Figure 2. The Counterfactual GDP for Greece: (a) with an EU Membership Predictor, and (b) without an EU Membership Predictor

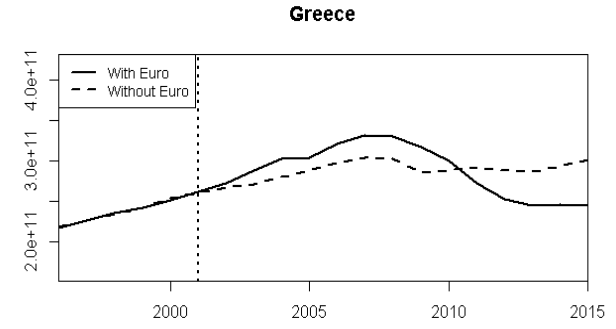

(a)

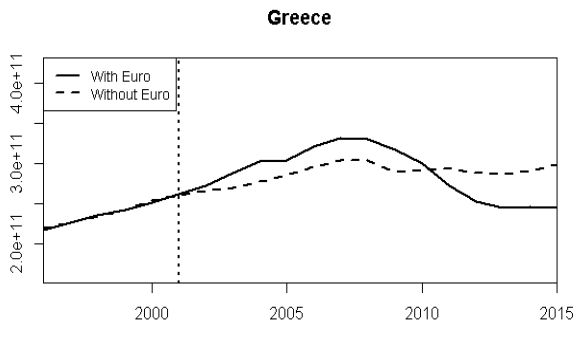

(b)

Why does euro membership seem to affect different countries in different ways? While the synthetic counterfactual method has certain advantages in comparative studies, it does not allow quantifying the contribution of each predictor to the overall effect. Examining the factor weights in matrix $V$ might serve such a purpose. However, there is yet no theory establishing a causal relationship between these weights and the outcome variable. Therefore, providing an explanation for the calculated differences between the actual and counterfactual outcomes is beyond the scope of this paper. Further research may look at how the optimum currency area criteria, such as cross border labour mobility, economic diversification, and macroeconomic policies apply to each country and time in search for clues about the causes of the differences.

\section{Sensitivity Analysis}

The synthetic counterfactual method does not provide, for the moment, standard deviations for the predicted outcomes. Instead, the authors of the method propose a "placebo" exercise that consists in computing a synthetic counterfactual for a non-treated unit and hoping to find no significant effect. This method has several shortcomings. First, it assumes independence of treatment across units, which is hardly the case when studying the euro area. Second, it only allows a visual inspection and comparison, with no possibility of assessing statistical significance. Some studies use difference-in-differences 
between the actual and counterfactual series to obtain some standard deviations of the predicted outcome (Campos et al., 2014, p. 19), an approach which appears to be flawed (Bertrand, Duflo and Mullainathan, 2004).

The sensitivity of the model with respect to the choice of the countries in the control group is determined by a resampling simulation, which provides lower and upper limits of the synthetic counterfactual effect. The simulation approach constructs 41 subsamples of countries by removing one country at a time and re-calculates the synthetic counterfactual outcome for each subsample. Resampling also allows estimating standard deviations of the outcome. Sensitivity analysis is only performed for Greece, being one of the most important cases in the study sample. Table 3 shows the summary results of the resampling exercise: the average counterfactual GDP for each year, its standard deviation, lower and upper bounds of a 95\% confidence interval based on a $t$ distribution for the counterfactual GDP, and the actual GDP. Based on the results calculated in Table 3, Figure 3 presents a plot of the actual GDP and the lower and upper bounds of the $95 \%$ confidence interval of the synthetic counterfactual GDP.

Table 3. The Results from a Resampling Simulation to Determine Standard Deviations for the Counterfactual GDP Series (The Case of Greece)

\begin{tabular}{|c|c|c|c|c|c|}
\hline Year & Average & St. Dev. & $\begin{array}{c}\text { Lower } \\
\text { Bound }\end{array}$ & $\begin{array}{c}\text { Upper } \\
\text { Bound }\end{array}$ & Actual \\
\hline 1998 & $2.34 \mathrm{E}+11$ & $2.44 \mathrm{E}+09$ & $2.29 \mathrm{E}+11$ & $2.39 \mathrm{E}+11$ & $2.35 \mathrm{E}+11$ \\
\hline 1999 & $2.43 \mathrm{E}+11$ & $2.64 \mathrm{E}+09$ & $2.37 \mathrm{E}+11$ & $2.48 \mathrm{E}+11$ & $2.42 \mathrm{E}+11$ \\
\hline 2000 & $2.55 \mathrm{E}+11$ & $2.96 \mathrm{E}+09$ & $2.49 \mathrm{E}+11$ & $2.61 \mathrm{E}+11$ & $2.52 \mathrm{E}+11$ \\
\hline 2001 & $2.6 \mathrm{E}+11$ & $3.36 \mathrm{E}+09$ & $2.53 \mathrm{E}+11$ & $2.68 \mathrm{E}+11$ & $2.62 \mathrm{E}+11$ \\
\hline 2002 & $2.65 \mathrm{E}+11$ & $4.17 \mathrm{E}+09$ & $2.56 \mathrm{E}+11$ & $2.74 \mathrm{E}+11$ & $2.72 \mathrm{E}+11$ \\
\hline 2003 & $2.68 \mathrm{E}+11$ & $5.31 \mathrm{E}+09$ & $2.57 \mathrm{E}+11$ & $2.8 \mathrm{E}+11$ & $2.88 \mathrm{E}+11$ \\
\hline 2004 & $2.76 \mathrm{E}+11$ & $6.21 \mathrm{E}+09$ & $2.63 \mathrm{E}+11$ & $2.89 \mathrm{E}+11$ & $3.03 \mathrm{E}+11$ \\
\hline 2005 & $2.84 \mathrm{E}+11$ & $7.55 \mathrm{E}+09$ & $2.68 \mathrm{E}+11$ & $3 \mathrm{E}+11$ & $3.04 \mathrm{E}+11$ \\
\hline 2006 & $2.95 \mathrm{E}+11$ & $8.66 \mathrm{E}+09$ & $2.77 \mathrm{E}+11$ & $3.13 \mathrm{E}+11$ & $3.22 \mathrm{E}+11$ \\
\hline 2007 & $3.03 \mathrm{E}+11$ & $9.88 \mathrm{E}+09$ & $2.82 \mathrm{E}+11$ & $3.24 \mathrm{E}+11$ & $3.32 \mathrm{E}+11$ \\
\hline 2008 & $3.02 \mathrm{E}+11$ & $1.02 \mathrm{E}+10$ & $2.8 \mathrm{E}+11$ & $3.23 \mathrm{E}+11$ & $3.31 \mathrm{E}+11$ \\
\hline 2009 & $2.88 \mathrm{E}+11$ & $1.01 \mathrm{E}+10$ & $2.67 \mathrm{E}+11$ & $3.09 \mathrm{E}+11$ & $3.17 \mathrm{E}+11$ \\
\hline 2010 & $2.93 \mathrm{E}+11$ & $1.06 \mathrm{E}+10$ & $2.7 \mathrm{E}+11$ & $3.15 \mathrm{E}+11$ & $2.99 \mathrm{E}+11$ \\
\hline 2011 & $2.97 \mathrm{E}+11$ & $1.18 \mathrm{E}+10$ & $2.72 \mathrm{E}+11$ & $3.22 \mathrm{E}+11$ & $2.72 \mathrm{E}+11$ \\
\hline 2012 & $2.94 \mathrm{E}+11$ & $1.25 \mathrm{E}+10$ & $2.68 \mathrm{E}+11$ & $3.2 \mathrm{E}+11$ & $2.52 \mathrm{E}+11$ \\
\hline 2013 & $2.94 \mathrm{E}+11$ & $1.32 \mathrm{E}+10$ & $2.66 \mathrm{E}+11$ & $3.22 \mathrm{E}+11$ & $2.44 \mathrm{E}+11$ \\
\hline 2014 & $2.99 \mathrm{E}+11$ & $1.42 \mathrm{E}+10$ & $2.69 \mathrm{E}+11$ & $3.29 \mathrm{E}+11$ & $2.46 \mathrm{E}+11$ \\
\hline 2015 & $3.08 \mathrm{E}+11$ & $1.56 \mathrm{E}+10$ & $2.75 \mathrm{E}+11$ & $3.41 \mathrm{E}+11$ & $2.45 \mathrm{E}+11$ \\
\hline
\end{tabular}

The simulation results show that the predicted counterfactual remains robust for Greece when the comparison group of countries changes. As a byproduct, the simulation reveals that the United States is among the most influential country in the control group: removing it noticeably reduces the positive effect of the euro on GDP. Figure 3 is also a good reminder that the 
synthetic counterfactual estimates depicted in Figure 1 are subject to potentially large fluctuations when the control group of countries changes.

Figure 3. Actual GDP and the $95 \%$ Confidence Interval Bounds for the Counterfactual GDP (the case of Greece)

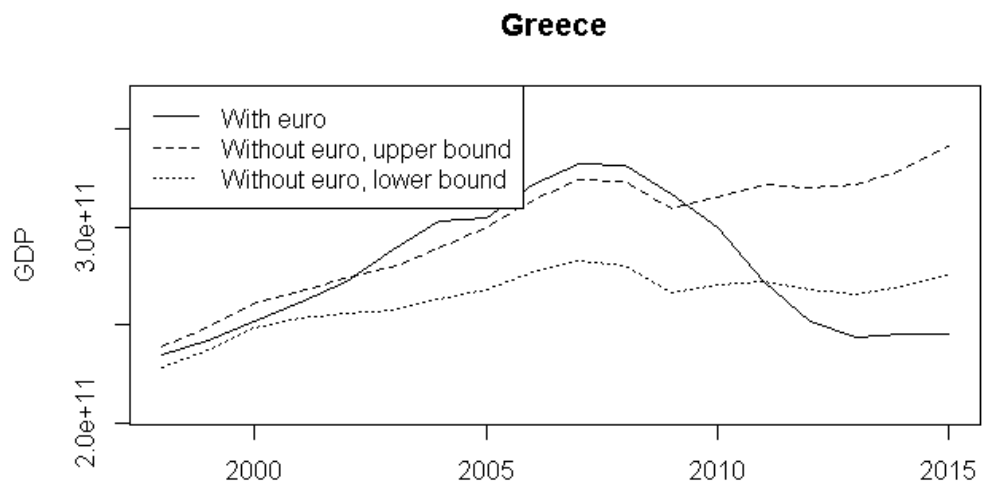

\section{The Effect of Common Currency on Inflation}

It is shown that the effect of the euro on GDP is quite different for different countries and time periods. There is no general conclusion that euro membership would be, on average, either good or bad for all countries at all times. Perhaps, the benefits of common currency are not solely reflected in higher national GDP levels, but rather in other measures of economic activity. One argument in favour of a common currency is economic stability, which includes price stability.

Would prices have been more volatile if a country stayed out of the euro area? Let us try to answer this question using the synthetic counterfactual method. The algorithm yields the counterfactual inflation series, $Y_{1 t}$ in equation (3), based on a set of predictors $X$ that help calculate the weights $W$ and $V$ (these weights are not the same as in the case of GDP.) For a few euro area countries, Table 4 tests the equality of the means and standard deviations of the actual vs. counterfactual series of CPI inflation rates over the period between 1996 and 2013.The null hypothesis of the test is that the means are equal. The results in the table show high $p$-values, which do not reject the null hypothesis of equal means. In other words, there is no evidence that the average inflation would have been different if the country did not join the Eurozone. The table also shows no significant differences in standard deviations between actual and counterfactual inflation rates (with the notable exception of Ireland), which suggests that price stability may not be enhanced by the adoption of the euro. 
Table 4. $p$-Values for Equality of Means and Standard Deviations in inflation

\begin{tabular}{|l|c|c|}
\hline Country & $\begin{array}{c}\boldsymbol{t} \text {-test for mean equality } \\
\mathbf{H}_{\mathbf{0}} \mathbf{:} \text { means are equal }\end{array}$ & $\begin{array}{c}\text { Levene's test of equality of standard } \\
\text { deviations }\end{array}$ \\
\hline Portugal & 0.9 & $\mathbf{H}_{\mathbf{0}}:$ standard deviations are equal \\
\hline Greece & 1 & 0.43 \\
\hline Italy & 0.6 & 0.71 \\
\hline Spain & 0.6 & 0.68 \\
\hline Ireland & 0.7 & 0.83 \\
\hline France & 0.3 & 0.03 \\
\hline Germany & 0.1 & 0.72 \\
\hline Slovenia & 0.3 & 0.58 \\
\hline
\end{tabular}

\section{The Effect of Common Currency on Exchange Rate and Debt}

In general, the present study suggests that there is no universal law stating the effect of a common currency on GDP or inflation. Where else could one look for an unequivocal effect of a common currency? As mentioned in the introductory section, one of the reasons of adopting the euro was the frustration of the European leaders with the wild fluctuations in bilateral exchange rates before and after the Europe's Exchange Rate Mechanism arrangement. However, El-Shagi et al., (2014) suggest that, at least for a few countries, such as reland, Portugal and Greece, adopting the euro did not actually solve fluctuation problems.

Another reason for adopting a common currency system in Europe is to force fiscal discipline on governments that historically run large public debts. The common currency comes with the Stability and Growth Pact, a mandatory set of rules requiring that a member should not have a public debt in excess of $60 \%$ of GDP. A synthetic counterfactual exercise can be done to determine whether government debt is influenced by the monetary union and its accompanying package of regulatory constraints.

For a few countries, Table 5 tests the equality of means and standard deviations of central government debt, expressed as percentage of GDP, between actual and counterfactual time series. This table shows a more intriguing picture than the inflation results in Table 4. According to Table 5 some countries, such as Portugal and Greece, seem to experience a higher average debt than if they did not join the euro area. For other countries, such as Germany, the actual and counterfactual averages are equal, but its debt has been stabilised by the euro membership. Yet for other countries, such as Ireland, the average debt is the same, but the standard deviation is greater with membership than without it. 
Table 5. p-Values for Equality of Means and Standard Deviations in Government Debt (\% of GDP)

\begin{tabular}{|c|c|c|c|}
\hline Country & $\begin{array}{c}\text { t-test for mean } \\
\text { equality } \\
\mathrm{H}_{0} \text { : } \text { means are } \\
\text { equal }\end{array}$ & $\begin{array}{c}\text { Levene's test of } \\
\text { equality of standard } \\
\text { deviations } \\
\mathbf{H}_{0}: \text { standard } \\
\text { deviations are equal }\end{array}$ & $\begin{array}{c}\text { Notes } \\
\mathbf{C}=\text { "counterfactual" } \\
\mathbf{A}=\text { "actual" }\end{array}$ \\
\hline Portugal & $6 e-04$ & 0.047 & $\operatorname{mean}(\mathrm{C})<\operatorname{mean}(\mathrm{A})$ \\
\hline Greece & $1 e-14$ & 0.51 & $\operatorname{mean}(\mathrm{C})<\operatorname{mean}(\mathrm{A})$ \\
\hline Italy & $2 e-16$ & 0.73 & $\operatorname{mean}(\mathrm{C})<\operatorname{mean}(\mathrm{A})$ \\
\hline Spain & $4 \mathrm{e}-02$ & 0.53 & $\operatorname{mean}(\mathrm{C})>\operatorname{mean}(\mathrm{A})$ \\
\hline Ireland & 0.2 & $6.6 e-03$ & $\operatorname{std}(\mathrm{C})<\operatorname{std}(\mathrm{A})$ \\
\hline France & $6 e-04$ & 0.094 & $\operatorname{mean}(\mathrm{C})>\operatorname{mean}(\mathrm{A})$ \\
\hline Germany & 0.3 & 0.054 & $\operatorname{std}(\mathrm{C})>\operatorname{std}(\mathrm{A})$ \\
\hline Slovenia & 0.8 & 0.82 & $\mathrm{H}_{0}$ not rejected \\
\hline
\end{tabular}

\section{Conclusion}

Using a synthetic counterfactual method, we find evidence that the adoption of the euro has had a significant impact on GDP in some countries, but the effect is not generally positive or negative and varies significantly across countries. Moreover, the effect appears to be changing over time from beneficial to detrimental or the other way around in some countries. This finding appears to be consistent with the literature on monetary integration or exchange rate regimes, which suggests that the effect of the exchange rate on economic growth is fundamentally country-specific. This method does not allow specifying what exactly determines the differences across countries, but it vividly reveals these differences.

The same can be stated about other macroeconomic variables, such as inflation and government debt. Other studies show that even real exchange rate stability, which is an important objective of the common currency is not achieved in all countries by the common currency (El-Shagi et al., 2014). Thus, the macroeconomic benefits of the European currency union are not to be taken for granted, and the decision whether to become a member (or to stay a member for that matter) should ponder an individual country's circumstances. In this regard, this study provides a useful framework when analysing individual countries that may (re-) consider their euro area membership.

\section{References}

Abadie, A., \& Gardeazabal, J. (2003). The Economic Costs of Conflict: A Case Study of the Basque Country. The American Economic Review, 113-132.

Abadie, A., Diamond, A., \& Hainmueller, J. (2010). Synthetic Control Methods for Comparative Case Studies: Estimating the Effect of California's Tobacco Control Program. Journal of the American Statistical Association, 493-505. 
Abadie, A., Diamond, A., \& Hainmueller, J. (2011). Synth: An R Package for Synthetic Control Methods in Comparative Case Studies. Journal of Statistical Software, 42(13), 1-17. Retrieved from http://www.jstatsoft.org/v42/i13/paper

Alessina, A., \& Barro, R. (2002). Currency Unions. The Quarterly Journal of Economics, 409-436.

Baikan, I. O. (2016). The Effects of Exchange Rate Regimes on Economic Growth: Evidence from Propensity Score Matching Estimates. Journal of Applied Statistics, 914-924.

Bailliu, J., Lafrance, R., \& Perrault, J.-F. (2002). Does Exchange Rate Policy Matter for Growth? Bank of Canada. Ottawa: Bank of Canada. Retrieved November 13, 2016, from http://www.bankofcanada.ca/wp-content/uploads/2010/02/wp0217.pdf

Baldwin, R. E., \& Forslid, R. (2000). Trade Liberalization and Endogenous Growth: A q-Theory Approach. Journal of International Economics, 497-517.

Bertrand, M., Duflo, E., \& Mullainathan, S. (2004). How much should we trust differences-in-differences estimates? The Quarterly Journal of Economics, 249275.

Billmaer, A., \& Nanncini, T. (2013). Assessing Economic Liberalization Episodes: A Synthetic Control Approach. The Review of Economic Statistics, 983-1001.

Breton, T. R. (2013). The role of education in economic growth: Theory, history and current returns. Educational Research, 121.

Campos, N., Coricelli, F., \& Moretti, L. (2014, April). Economic Growth and Political Integration:Estimating the Benefits from Membership in the European Union Using the Synthetic Counterfactuals Method. Bonn: Institute for the Study of Labour (IZA).

Conti, M. (2014). The Introduction of the Euro and Economic Growth: Some Panel Data Evidence. Journal of Applied Economics, 199-211.

Dees, S., Mauro, F. D., Pesaran, H., \& Smith, V. (2007). Exploring the International Linkages in the Euro Area: A Global VAR Analysis. Jopurnal of Applied Econometrics, 22(1), 1-38. doi:10.1002/jae.932

Eisner, R. (1992). Deficits: Which, how much, and so what? The American Economic Review, 295-298.

El-Shagi, M., Lindner, A., \& Schweinitz, G. v. (2014). Real Effective Exchange Rate Misalignment in the Euro Area: A Counterfactual Analysis. IWH Discussion Papers(6).

Imbens, G., \& Wooldridge, J. (2009). Recent Developments in the Econometrics of Program Evaluation. Journal of Economic Literature, 5-86.

Kalaitzoglu, I., \& Durgheu, B. (2016). Financial and Economic Growth in Europe: Is the Euro Beneficial for All Countries? Journal of Economic Integration, 414-471.

Levy-Yevati, E., \& Sturzenegger, F. (2003). To Float or to Fix: Evidence on the Impact of Exchange Rate. The American Economic Review, 1173-1193.

Mankiw, N. G., Romer, D., \& Weil, D. N. (1992). A Contribution to the Empirics of Economic Growth. The Quarterly Journal of Economics, 407-437.

Montalvo, J. G. (2011). Voting after thte Bombings: A Natural Experiment on the Effect of Terrorist Attacks on Democratic Elections. The Review of Economics and Statistics, 1146-1154.

Papanikos, G. T. (2015). The Real Exchange Rate of Euro and Greek Economic Growth. Journal of Economic Asymmetries, 100-109.

Solow, R. M. (1956). A contribution to the theory of economic growth. Quarterly Journal of Economics, 65-94.

Solow, R. M. (1957). Technical change and the aggregate production function. Review 
Vol. 3, No. 2 Colonescu: Macroeconomic Effects of the European Monetary Union...

of Economics and Statistics, 312-320.

Swan, T. (1956). Economic growth and capital accumulation. Economic Record (Wiley), 334-361.

Vickers, J. (2000). Monetary Union and Economic Growth. Brussels: National Bank of Belgium. Retrieved June 19, 2015, from https://www.nbb.be/doc/ts/publications/ wp/wp10en.pdf

World Bank. (2016). World Development Indicators. Retrieved November 10, 2016, from http://databank.worldbank.org/data/views/variableSelection/selectvariables. aspx?source $=$ world-development-indicators 